\title{
The Survival of the Kurdish Chicken: Uneven Development and Nationalist Discourse in the Kurdistan Region of Iraq
}

\author{
Andrea Fischer-Tahir
}

\section{Research Question and Positionality}

In the spring of 2016, the Iraqi government banned the sale of poultry from the Kurdistan Region to the center and south of the country. Some months before, Baghdad had already banned the import of poultry from more than twenty countries after reports on the outbreak of avian influenza in other parts of the world. In the same vein, the Kurdistan Regional Government (KRG) banned poultry imports, including from other parts of Iraq, and repeated this ban in January 2017 after cases of avian influenza had been detected in the Iraqi province of Diyala. ${ }^{1}$ A colleague of mine, living in the Kurdish city of Sulaimaniya, keeps chickens on the roof of her parent's house. Her birds were highly affected by the influenza, as she writes: "Initially there were twelve, but the bird flu took half of them. Now I'm crossing my fingers that others survive."2

After the long years of economic crisis, poultry production in Kurdistan has grown over the last decade, including an increase of $40 \%$ in just the last five years (Abdullah 2018). According to official statistics, more than 1300 poultry farms produced 108,000 metric tons in 2017, and experts believe that the region "could technically sustain its own demand" (Abdullah 2018). However, the Kurdish Regional Government (KRG) promotes food imports; in 2017, it imported an additional 60,000 metric tons. ${ }^{3}$ Foreign companies, above all from Turkey, sell their goods for lower prices while being legally protected as international

\footnotetext{
A. Fischer-Tahir $(\bowtie)$

Institut für Erziehungswissenschaften, Technische Universität Dresden,

Dresden, Germany

e-mail: andreatahir@gmx.de
}

(C) The Author(s) 2021

R. Ouaissa et al. (eds.), Re-Configurations, Politik und Gesellschaft des Nahen

Ostens, https://doi.org/10.1007/978-3-658-31160-5_8 
businesses. As a result, Kurdish producers are forced to sell their poultry to other parts of Iraq. Thus, Kurdish chickens have three major enemies: humans, viruses, and the capitalist mode of production. In this chapter, I will proceed to discuss the following questions: In which ways are uneven development and neoliberalism inscribed in the Kurdish project of independence? Is foreign trade with Turkey at odds with Kurdish nationalist sentiments? Finally, why do people raise chickens on their rooftops?

This chapter deals with political, economic, and social re-configurations and their interplay with representations of identity and taste. In using the term "re-configurations" according to the conceptual framework of this volume, I am referring to reproductive, cumulative, and transformative processes that are both interdependent and overlapping (Boudon 1979). A notion of human experience that involves spatial and temporal dimensions makes it possible to highlight the dynamics of change (Koselleck 2000, p. 12 f.). The chapter's argument also builds on a notion of "representation" that refers to the cultural practice of constructing meaning (Hall 1997). "Representations" can be understood as resources for action and forms of organized knowledge that shape how social systems of interaction are re-configured; at the same time, representations are subject to change (Baberowski 2009). This applies to more than abstract political symbols, narratives, power structures, and economic concepts and performances. It also extends to the modes of dressing, eating and drinking, furnishing, gardening, or of consuming art that comment on political and economic change (Newcomb 2006; Deeb and Harb 2013; Dimitova 2013). Hence, this chapter will consider the act of "keeping chickens on the roof" as a performance from the realm of everyday life so as to reflect on order and disorder in the Kurdistan Region.

I must admit that this chapter was written without conducting formal field research on the particular topic of "urban farming." However, my argument is grounded in long-standing research experience in Southern Kurdistan since 1993. Apart from that, I have had the chance to work in Kurdistan with foreign and local NGOs and as an employee and scholar in the higher-education sector. These activities, as well as my social relationships there over the last twenty-five years, have shaped and reshaped my political position on Kurdistan. Therefore, my academic writing on Kurdistan is far from any kind of imagined objectivity, but is instead guided by empathy and the spirit of critical solidarity. The idea for this paper was born after a friend of mine, another researcher in the field of Kurdish Studies, returned from Sulaimaniya and told me about "chickens on the roof." This provoked me to ask Kurdish friends and family about this on the phone or by email, and I began searching for more information in Kurdish media. Well-structured field work informed by practice theory (Bourdieu 1977) that 
involves participant observation, interviews, conversation, and reflexivity would lay better groundwork for discussing localized, positioned, and situated knowledge, as advocated by Donna Haraway (1988, p. 589; see also Sultana 2007). However, for personal reasons, I have not been able to visit Kurdistan in recent years to see and observe, to ask questions and to listen. Therefore, my chapter appears as a sort of "family-and-friends paper" written from a privileged spatial distance.

\section{The Chicken on the Roof}

Across class and spatial divisions, contemporary Kurdish households tend to consider chicken an integral part of their diet. ${ }^{4}$ In addition to kebabs made of minced lamb meat, fried chicken is one of the most popular dishes in restaurants and is routinely served to guests in private homes. However, the dominance of chicken is rather new: it results from modernist development and globalized commodity exchange. Thus, Henny H. Hansen's account of Kurdish Woman's Life suggests that, by the late 1950s, mutton was slightly preferred to fowl such as chicken or turkey (Hansen 1961, p. 49), and when asked what they consider to be "typical Kurdish food" (č $\hat{e} s ̧ t-\hat{\imath}$ kurdî), Kurds in Iraq tend to mention several dishes involving lamb or mutton in some form (cf. 2009, p. 164 ff.). It was the "modernization" projects of the 1970s pursued by the Iraqi Arab-nationalist Baath regime that introduced industrialized poultry farming. "Poultry farms" (abbreviated as dawäjin) were state-owned enterprises located in small towns or the outskirts of cities, whereas in villages they were quasi-socialist co-operation projects according to the agrarian reform law of 1970 (Gabbay 1978; Dzięgiel 1981; Genat 2017). These cooperations were, however, abolished by 1988 , when the regime launched its genocidal Anfal campaigns against the Peshmerga and village population (Middle East Watch 1993).

During the 1970s and 1980s, the agrarian sector underwent contradictory transformations. Thus, the oil boom of 1973 facilitated an expansion of food imports to Iraq. However, this led to the neglect of the domestic agrarian production. Based on food imports, the regime and welfare state established a food distribution system aimed at courting the support of low-income households and approval of the government's policies, but when expanded to the whole population the system became a means of discipline and control. At the beginning of the 1980s, tendencies to liberalize the economic sector emerged and intensified with the continued war against Iran (2003, p. 74 ff.; Springborg 1986; Leezenberg 2006). Due to the international embargo of Iraq after the invasion of Kuwait in 
1990, poultry production declined as the whole Iraqi economy collapsed; prices of major commodities such as flour, rice, sugar, tea, meat, gasoline, and kerosene exploded (Natali 2010, p. $29 \mathrm{ff}$.). The success of international humanitarian aid and rural reconstruction proved limited due to the embargo, Baghdad's ban on Kurdish insurgents, and the persistent climate of insecurity (Ofteringer and Bäcker 1994; Winter et al. 2002).

Since 2003, the reintegration of the Kurdistan Region into the Iraqi oil economy led to growing international capital investment and a multitude of business opportunities, which significantly improved the availability of basic food and meat in the market. Even eggs on sale in the new supermarkets often stem from poultry production in other countries, especially Turkey and Iran. Shops located in the old bazaars, the urban periphery, or small towns also sell eggs and chicken from local and national producers as well as from individual farms. At the same time, people pursue alternative ways to obtain eggs and "white meat." Thus, the city of Sulaimaniya is witnessing a revival of chicken-raising in courtyards and on the roofs of single-family dwellings. Recently, the above-mentioned colleague of mine from Sulaimaniya sent me pictures of these friendly animals on her roof and in the courtyard of her parents' house, a middle-class household with well-educated daughters. She wrote:

We keep them for their eggs and for our happiness.[...] I feed them cucumbers and bread in vegetable soup.[...] I feed them whatever scraps of food are left over from us. We never throw food away. ... We always find it hard to kill them to eat, but once or twice a year [...] my sisters ask someone to kill a chicken and they eat it while they speak of its happy days. ${ }^{5}$

This is interesting on four levels: nutrition, care for animal welfare, responsible use of resources, and the appropriation of nature for human pleasure. When discussing this specific practice with other Kurdish friends and relatives living in Sulaimaniya, I heard several statements of validation, approval, and further explanation. For example, "Kurdish chicken tastes better than imported frozen chicken; the eggs are healthier than those of the dawäjin." Another said: "This is our culture." Within this context, I also remembered elderly women from my husband's family saying at various occasions over the last twenty-five years: "Kurdish chicken (mirişk-î kurdî) tastes better than any other chicken in the world." Of course, they were referring to chicken raised by relatives in the village. This is "Kurdish chicken" as a marker of quality, taste, and identity. According to Bourdieu (1987), taste preferences are a result of social practice; they are class-based and represent cultural capital. Taste not only marks one's place in social hierarchies but it also reproduces social difference. Embedded in other performances of lifestyle, taste also can be displayed as a comment or critique 
of social hierarchies and injustice. This conceptual link raises the question: What kinds of hierarchies and injustices is this specific case referencing?

\section{Nationalism, Uneven Development, and Neoliberalism}

Since the popular uprising of March 1991, the Kurdistan Region underwent major political re-configurations. Today, it is a semi-independent territorial entity. This "unrecognized state" (Caspersen and Stansfield 2011) is ruled by a democratically elected government enacting domestic sovereignty over the four governorates of Dohuk, Erbil, Sulaimaniya, and Halabja. In September 2017, a referendum for independence showed that $92.7 \%$ of the voters supported separation from Iraq. ${ }^{6}$ The regional elections in September 2018 showed approval of the ruling parties: $44 \%$ for the Barzani-led Kurdistan Democratic Party (KDP) and $20.5 \%$ for the Patriotic Union of Kurdistan (PUK). Among the parties who had formed a governing coalition with these two in 2014, it was $12 \%$ for the Sulaimaniya-based Change Movement (Gorran), 7\% for the Islamic Group, and 5 for the Islamic Union of Kurdistan. ${ }^{7}$ Kurdish nationalism is still the dominant ideology in the region, and these three oppositional forces were incorporated into the previous government in order to silence resistance and to avoid armed conflict among Kurdish parties. In regard to international relations, the KRG maintains diplomatic ties and negotiates military arrangements with foreign powers; it also contracts with oil companies from such countries as China, Russia, the United States, Norway, and Turkey. ${ }^{8}$ At the same time, Kurdish factions have been part of the Iraqi parliament and government since 2005, and the appointed president of post-Baath Iraq has always been a Kurd from the PUK leadership, from Jalal Talaban and Fuad Masum to Barham Salih. Nevertheless, the relationship between Baghdad and Erbil remains fragile. In particular, disputes over territory and the control of hydrocarbon resources have caused serious conflicts and led to armed confrontation. Thus, Haidar al-Abadi's government reacted to the referendum by re-conquering the oil-rich area and the city of Kirkuk, which the Peshmerga have controlled since the US-led invasion of Iraq in $2003 .{ }^{9}$

When Kurds transformed their decade-long struggle for self-determination into a semi-state, they had to cope with the experience of war and genocidal persecution (2003; Mlodoch 2014). After 1991, the climate of violence persisted due to invasions of the Turkish and Iranian neighbors, the Kurdish militia war, the intervention of the Iraqi regime, the US-led invasion, and, recently, the war against the quasi-fascist "Islamic State" (IS). Nevertheless, the Kurdistan Region has managed to implement some sort of "late-modernist" development, focusing 
not only on the oil sector, but also on urban reconstruction, transport infrastructure, communication, international trade, higher education, leisure, and tourism. As in other parts of the world, this development has resembled a sort of "megalomania," and the ruling elites established the narrative of Kurdistan as the Iraqi Dubai (Sama 2015). In this transformation, government investment is hardly distinguishable from private domestic capital. Leading political figures and their relatives also perform key roles in the economy and are financial sponsors of media, art, and higher education. At the same time, there is no transparency at all about the state's financial plan. Harsh measures against journalists investigating corruption and maladministration exemplify the increasing authoritarianism of the ruling parties (Watts 2014, 2017).

Since 2003, the Kurdistan Region has been witnessing the disintegration of the post-revolutionary distribution system that had been partly based on the old Iraqi welfare state. The government supports the neoliberal transformations through legal regulations. The Law of Investment issued in 2006 was designed to advance economic change; its articles pledge to facilitate economic activities such as capital transactions and buying or leasing land while exempting international investors from all taxes (except tariffs) for the first ten years. ${ }^{10}$ Economic experts stress that the implementation of the law has successfully promoted integration into the global economy (Heshmati 2010). The Kurdistan Region, with its booming center of Erbil, became "a place to see" attracting foreign capital as well as tourists. The former periphery of Iraq transformed into a center of development. However, it is uncertain how long Kurdistan will remain attractive for capital investment; today's privileged situation is mainly due to lasting insecurity in the "rest of Iraq." In addition, development is not equally "distributed." Instead, spatial differentiation between governorates is growing. As the most powerful parts of the political elites (KDP) reside in Erbil and Dohuk, these cities are most favored, whereas Sulaimaniya and Halabja benefit less from the "boom"- - even though Halabja is widely recognized in Kurdish discourse as the most powerful symbol of genocidal persecution (2012; Watts 2017). These inner peripheries greatly suffered between 2014 and 2018, when the KRG repeatedly ordered the suspension of public-sector salaries, presenting the war against IS and the uncooperative government in Baghdad as justifications. Meanwhile, business seemed to be proceeding as usual for the political-economic elites.

Peripheralization is not a new phenomenon in Kurdistan. European colonialism and Iraqi inner colonialism put the region at the margins of both the global and the national socio-economic and political orders. The novelty is the concurrence of the Kurdistan Region's de-peripheralization on the national scale (of Iraq) with re-peripheralization on a sub-national scale (Kurdistan). However, 
neither the old nor the new forms of peripheralization should be seen as a mismatch for (late) "modernization." Rather, as critical geographer Neil Smith (1984) would say, they result from the logic of capital accumulation and "normal" capitalist development, which is uneven in space and time.

According to the re-configurations outlined so far, neoliberalism's "pervasive affects ... on ways of thought and political-economic practice" (Harvey 2007, p. 23) are also true for other sectors as health care and higher education. Over the past decade, a growing number of private hospitals have opened, reinforcing a notion that health care is tied to social class. At the same time, medical treatment became more costly in state-run hospitals and dramatically exceeded a household's monthly income and savings especially in cases of cancer or renal diseases. Kurdistan had three universities in 2003. Today, there are fifteen more, half of them private, among them two American universities, one controlled by the Barzani family, the other by Barham Salih. Private universities require tuition fees denominated in US dollars and the "right" social and political contacts. Due to the focus on commercial and business studies, the use of English as the language of instruction, and staff comprised of "Westerners" and highly qualified Diaspora returnees, their degrees are more valued than those of state universities, which improves private students' prospects. Thus, the re-configuration of higher education has led to new social injustice while reproducing older social hierarchies.

Neoliberalism also affects other spheres of life. For example, neoliberal techniques have changed patterns of media production and journalistic representation with significant effects on political and social discourses. Interestingly, Kurdish nationalism remains the hegemonic narrative in the media (2017). Similarly, Schluwa Sama's (2015) research on shopping malls shows that the neoliberal ideology of success, exclusivity, and self-presentation is perfectly compatible with Kurdish nationalist narratives of moral superiority over "the Arabs" and migrant workers. In addition, another aspect of urban reconstruction indicates that nationalism is not a contradiction to neoliberalism. As elsewhere in West Asia and North Africa, "late-modernist" development can be combined with the desire for celebrating cultural heritage. Thus, selected historical sites and buildings (most prominently the citadel of Erbil) have become subject to revaluation, restoration, and integration or interconnection with other projects such as luxury hotels or shopping areas. At the same time, the cities have seen a proliferation of cafés and restaurants offering "Kurdish food" at "Western" prices, to be enjoyed in new buildings or in renovated old city houses, both with folkloristic interior decoration. These are exclusive spaces for consumption, social networking, political discussion, business, and self-presentation. During my last visit to Kurdistan, in spring 2016, I was in the courtyard of such a re-functioned city house 
in Sulaimaniya when I had the opportunity to meet an unexpected coeval-the free-range chicken. When I asked why chickens would be kept in such places, the answer was "This is part of our culture."

\section{Change, Continuity, and the Chicken}

The Kurdistan Region's two major functions within contemporary global capitalism are as a market and as a supplier of natural resources. As indicated earlier, this has serious effects on Kurdistan's domestic production. In 2015, for example, government officials stated that about $90 \%$ of food available in the local market was imported, while at the same time the government allocated only two percent of the annual budget to the agricultural sector (Abdullah 2015). As for poultry production, local enterprises as well as individual farmers face difficulties selling their chicken in local markets because companies from Turkey, Iran, France, China, South Africa, and elsewhere sell chicken and eggs at lower prices. The import business in Kurdistan is in the tight grip of Kurdish merchants who are entangled with ruling elites, explaining the lack of legal measures to regulate prices in a way that would strengthen the position of local "meat producers" (Handani 2017). The neglect of the agricultural sector while pinning all hopes for a great future on oil and gas reflects a sort of rentier-state mentality, partly inherited from Iraq and partly adopted with Kurdistan's increasing integration into the global economy. As far as I could observe on previous visits, public opinion in Kurdistan considers dependence on imported goods to be a threat to domestic food production. In the media, agricultural experts and other economists criticize the lack of proper planning and warn of consequences for the domestic agriculture. Farmers and city dwellers make similar arguments, as Katharina Lange (2016) has shown for the province of Dohuk. However, interviewees several years earlier were already pointing to the dangers of oil dependency, and specifically United Nations the "oil-for-food" program implemented in 1997 to absorb the dramatic effects of the embargo against Iraq. Whereas humanitarian aid after 1991 had aimed at rebuilding villages and rehabilitating agriculture, the "oil-for-food" program partly stopped this process and reanimated the Iraqi food distribution system (2011). Hence, dependency on food imports is not new. What has changed are the major players in food imports, and in general the economic dominance of Turkey. In recent years, I have often heard rhetorical questions such as "Why do we allow the Kurds' enemies to flood our bazaar with their goods? Don't we have our own tomatoes, potatoes, eggs, and meat?" Such questions merge a critique of 
dependency with Kurdish nationalist discourse. At the same time, the prevailing dependency shows that re-configurations involve both change and continuity.

Turning to the level of food consumption, chicken presents more evidence that change and continuity are simultaneous. In comparison to the "Kurdish chicken" from the village, frozen animals delivered through transnational commodity chains seem to offer advantages besides their lower prices. For one thing, they are easier to get-for example, when driving home from work, passing by a shop in the neighborhood, or one of the new supermarkets. This avoids a time-consuming visit to the central bazaar in the heavily trafficked downtown where fresh meat and local goods are sold. Women in particular prefer not to go to the "meat market," as it is considered "dirty," "unhygienic," and "male." Interestingly, the standardized chicken also changes cooking and eating habits. As far as I observed in the past, Kurdish women used to cook the feet for little children; this not only provided them with extra calcium, but also kept them busy and silent for a while. However, the standardized chicken arrives in Kurdistan without its feet. In addition, due to the destructive character of capitalist "meat production," imported chickens are female, and so men miss the cock that is considered a delicacy. Last but not least, relations of commodity circulation affect the ways chicken is consumed: either on the table or on a table-cloth spread on the floor. The parts of a chicken used to be distributed according to social hierarchy, the cultural value of innards and outer parts, and socially defined needs. Accordingly, taste preferences were constructed und justified in social discourse (2009, p. 164 ff.). The standardized chicken disturbs this order because of the specificity of the chicken's body in terms of proportions, inner organs, head and feet, but it does not lead to abolishing inequality at the table under male domination. Either way, special guests will be served a "Kurdish chicken," for it seems to be consensus that the village-based chicken is much better. Moreover, "Kurdish chicken" is said not to be contaminated with antibiotics or biogenetic amines, defects predominantly to be found in imported chicken (Murad 2013).

My colleague in Sulaimaniya who keeps chickens on the roof confirmed the concern for healthy food, referring to "frequent media and private conversations about the nutritional value of fresh free-range eggs and meat."11 She thus addresses one of the multiple reasons for urban people to keep their own chickens instead of being very dependent on imported food that might be a threat to health. Indeed, this health discourse is influenced by global discourses on healthy and organic food as well as the revaluation of "the natural" and moves of re-turning to nature. In connection with these discourses, middle-class city dwellers have rediscovered the urban garden or begun to buy plots of land outside of town for 
planting vegetables, fruit trees, and flowers. These people seek rest and relaxation from the city, which they see as overloaded with traffic, construction noise, noxious substances, a hectic pace, and political struggles. I often heard relatives and friends justifying these "returns to nature" by referring to village and agrarian society as genuine aspects of Kurdishness. In the same vein, an agrarian scientist published an encyclopedia of herbology aiming at preserving knowledge about the nutritional value and healing powers of herbs in general, particularly those growing in Kurdistan (Ghefur 2012). In addition, my colleague stressed that keeping chickens in the city is a tradition, and writes:

[I]n our neighborhood on the upper side of town (known as the traditional neighborhood), families have always kept animals. I remember seeing some of neighbors and others closer to the mountain of Goyzhe even keep sheep and goats until the late 1990s. ${ }^{12}$

Later this practice disappeared somehow, but "lately it has become trendier ... perhaps due to the financial crisis," that is, the suspension of salaries when Erbil and Baghdad quarreled over the budget of the Kurdistan Region. Past, present, and future have a pervasive influence. Meanwhile, coping strategies merge with narratives of Kurdish identity to produce critical comments on what the ruling elites promote as "development."

\section{The (A-)Political at the End}

The return to nature- - be it the chicken on the urban roof and courtyard, the urban garden, or the urban part-time farmer-also seems related to structural problems with the political culture in Kurdistan. The KRG is well-trained in channeling political opposition. Long before the Arab Spring, Kurds in Iraq regularly took to the streets to protest maladministration and corruption. A strong civil society developed that includes a broad spectrum of social, political, economic and cultural interest groups. However, two main structural aspects of Kurdish society and political culture have so far prevented successful social revolutionary upheaval. First, there is the incorporative power of the post-revolutionary system and rentier-state; in one way or another, the individuals are placed within the system through kinship and other social networks. This helps them survive and improve their own situations and positions. Secondly, Kurdish narratives of victimhood and the historically grounded legitimacy of the Kurdish right to self-determination have persistent mobilizing power. Thus, conflicts with external forces (outer enemies) are invoked to activate the Kurdish anti-colonial reflexes. To give an example, the referendum of 2017 was widely considered a success by 
the ruling elites and international media; as mentioned, more than $90 \%$ voted in favor of separation. However, the referendum for independence was held primarily in order to postpone regular elections in Kurdistan, to prolong Masud Barzani's presidency and power, and strengthen Erbil's position in relation to Baghdad. Even though Kurds have been aware of this, relatives I have heard criticizing the KRG often voted "yes" or even volunteered as polling clerks. Apart from that, a closer look at numbers is revealing: the referendum was characterized by a total voter turnout of $72 \%$, with Halabja only $55.6 \%$ and Sulaimaniya city only $47 \% .{ }^{13}$ A longtime friend of mine, herself a left-wing activist since the 1970 s, said: "I cannot vote 'yes' because it is all in the interest of the Barzanis. But neither can I vote 'no' because I am a Kurd. I have struggled my whole life for our self-determination." 14

During my most recent visit three years ago, this friend was also very much concerned with her garden, and we both agreed that planting and caring for flowers is a perfect escaping strategy in a disordered world that seems impossible to change in a profound, and not only superficial way.

At this point, let me return to the initial question: Why are there chickens on the roofs of houses in a Kurdish city? As I have tried to show, the answer lies in the dynamics of economic, political, and social re-configurations and in various discourses at work in these processes that involve both change and continuity. I would interpret this particular practice as an appropriation of nature, a comment of transformation processes, and a critique of "megalomania," alienation, and dependency on "the enemies of the Kurds". At the same time, this practice is in dialogue with global discourses on healthy nutrition, sustainability, and protection of the planet. It represents an attempt to change something in this disordered world, if only on a small scale.

\section{Endnotes}

1. "Iraq bans poultry imports from 24 countries over avian flu threat," Reuters, 10 Jan. 2016; "Kurdish poultry sales continue to decline after Iraqi import ban", Rudaw, 21 April 2016; "KRG bans chicken imports from 39 countries and amid bird flu epidemic", Rudaw, 31 Aug. 2018. See also Linden 2016.

2. Email exchange of the author with Shenah Abdullah, 2 Sept. 2018; quoted with her permission.

3. "KRG bans chicken imports ...", Rudaw, 31 Aug. 2018.

4. Kurds in Iraq distinguish between goştî spî ("white meat") referring predominantly to chicken and turkey and goştî sûr (red meat) referring to mutton/ lamb and calf (Awrehman Beg et al. 2008, p. 4).

5. Email exchange with Shenah Abdullah, see footnote 2. 
6. See, press release of the Independent High Election and Referendum Commission, 27 Sept. 2017 (www.khrc.krd. Accessed: 10 April 2019).

7. NRT, 27 Sept. 2018.

8. For a list of oil companies in Kurdistan, see www.iraq-business.com. Accessed: 10 April 2018.

9. See, press release of the Kurdistan Regional Government, 25 Oct. 2017 (www.krg.org. Accessed: 10 April 2019).

10. Kurdistan Regional Government, "Law of Investment" issued in 2006 (see, www.cabinet.gov.krd. Accessed 5 Nov. 2018).

11. Email exchange with Shenah Abdullah, see footnote 2.

12. Ibid.

13. "Rêje-î dengdan leser cem parêzgakan blawdekatewe" [Voting results of all governorates are published], Speemedia 27 Sept. 2017 (www.speemedia. com. Accessed: 10 April 2019).

14. Talk on the phone with Wazira Jalal, Director of the local NGO New Life for Anfal Women, Sulaimaniya; September 2017.

\section{References}

Abdullah, Rawa. 2015. More than 90 percent of Kurdistan's food is imported. Rûdaw. https://www.rudaw.net/english/kurdistan/271120151. Accessed: 10 April 2019.

Abdullah, Rawa. 2018. Poultry farms flourish in Kurdistan, but cheap imports hold them back. Rûdaw. https://www.rudaw.net/english/business/03052018. Accessed: 10 April 2019.

Baberowski, J.örg. 2009. Was sind Repräsentationen sozialer Ordnungen im Wandel? Anmerkungen $\mathrm{zu}$ einer Geschichte. interkultureller Begegnung. In Arbeit an der Geschichte Wie viel Theorie braucht die Geschichtswissenschaft?, ed. J.örg Baberowski, 7-18. Frankfurt a. M.: Campus.

Awrehman Beg, R'anaxan Osman, M. Sh. Hemereşîd, and K. Muhammed. 2008. Hemû corekan-î xwardin. Xwardin-u çêş̧tlênan-u îş-î hewîr-u şîrîn. [All kinds of food. Cooking, pastry and sweet]. Sulaimaniya: Aram.

Boudon, Raymond. 1979. La logique du social. Introduction à l'analyse sociologique. Paris: Hachette Littérature.

Bourdieu, Pierre. 1977. Outline of a theory of practice. Cambridge: Cambridge University Press.

Bourdieu, Pierre. 1987. Distinction. A social critique of the judgment of taste. Cambridge: Harvard University Press.

Caspersen, N., and G. Stansfield (eds.). 2011. Unrecognized states in the international system. London: Routledge.

Deeb, Lara, and M. Harb. 2013. Leisurely Islam. Negotiating geography and morality in shiite South Beirut. Princeton: Princeton University Press. 
Dimitova, Rozita. 2013. Ethno-Baroque: Materiality, aesthetics and conflict in modern-day Macedonia. Oxford: Berghahn Books.

Dzięgiel, Leszek. 1981. Rural community and contemporary in Iraqi Kurdistan facing modernization. Krakow: Akademia Rolnicza w Krakowie.

Fischer-Tahir, Andrea. 2003. "Wir gaben viele Märtyrer": Widerstand und kollektive Identitätsbildung in Irakisch-Kurdistan. Münster: Unrast Verlag.

Fischer-Tahir, Andrea. 2009. Brave man, pretty woman? Gender and symbolic violence in Iraqi Kurdish urban society. Berlin: Europäisches Zentrum für Kurdische Studien.

Fischer-Tahir, Andrea. 2011. Representations of peripheral space in Iraqi Kurdistan. Études Rurales 186: 117-130.

Fischer-Tahir, Andrea. 2012. The concept of genocide as part of knowledge production in Iraqi Kurdistan. In Writing the history of Iraq: Historiographical and political challenges, ed. J. Tejel, R. Bocco, H. Bozarslan, and P. Sluglett, 226-243. London: World Scientific.

Fischer-Tahir, Andrea. 2017. Media, political culture, and the shadows of the militia war in Iraqi Kurdistan. In The Kurdish question revisited, ed. G. Stansfield and M. Shareef, 497-508. London: Hurst.

Gabbay, Rony. 1978. Communism and Agrarian reform in Iraq. London: Croom Helm.

Genat, Mélisande. 2017. From agrarian experiments to population displacement: Iraqi Kurdish collective towns in the context of socialist "villiagization" in the 1970s. In Disciplinary Space: Spatial Control, Forced Assimilation, and Narratives of Progress since the $19^{\text {th }}$ Century, Eds. A. Fischer Tahir and S. Wagenhofer, 137-64. Bielefeld: Transcript.

Ghefur, Kemal Cemal. 2012. Keleferheng-î ruweke abûriyekan betaybety le Kurdistan-da. [Encyclopaedy of economic plants]. Erbil: Aras.

Hall, Stuart (ed.). 1997. Representation: Cultural representations and signifying practices. London: Sage Publications.

Handani, Salam. 2017. Ruffled Feathers: Iraqi Kurdish Farmers Call Foul Play. Niqash. https://www.niqash.org/en/articles/economy/5657. Accessed: 10 April 2019.

Hansen, Henny Harald. 1961. The Kurdish woman's life. Field research in a Muslim society, Iraq. Copenhagen: Nationalmuseet.

Haraway, D. 1988. Situated knowledges: The science question in feminism and the privilege of partial perspective. Feminist Studies 14 (3): 575-599.

Harvey, D. 2007. Neoliberalism as creative destruction. The ANNALS of the American Academy of Political and Social Science 610 (1): 21-44.

Heshmati, Almas. 2010. The economy of southern Kurdistan. New York: Nova Science Publishers.

Koselleck, Reinhart. 2000. Zeitschichten. Studien zur Historik. Mit einem Beitrag von Hans-Georg Gadamer. Frankfurt a. M.: Suhrkamp.

Lange, Katharina. 2016. Verlust/Geschäft: Repräsentationen sozialen und wirtschaftlichen Wandels im ländlichen Dohuk (Kurdistan-Irak). In Ethnographien des Wandels im Nahen Osten und Nordafrika, ed. A. Fischer-Tahir and K. Lange, 203-222. Leipzig: Leipziger Universitätsverlag.

Leezenberg, Michiel. 2006. Urbanization, privatization, and patronage: The political economy of Iraqi Kurdistan. In The Kurds. Nationalism and politics, ed. F.A. Jabar and H. Dawod, 151-179. London: Saqi. 
Linden, Jackie. 2016. Poultry sector in Iraqi Kurdistan in decline. WATTAgNet. https:// www.wattagnet.com/articles/26694-poultry-sector-in-iraqi-kurdistan-in-decline. Accessed: 10 April 2019.

Middle East Watch. 1993. Genocide in Iraq. The Anfal campaign against the Kurds. New York: Human Rights Watch.

Mlodoch, Karin. 2014. The limits of trauma Ddscourse. Women Anfal survivors in Kurdistan-Iraq. Berlin: Klaus Schwarz Verlag.

Murad, Hayhaow O. M. 2013. Detection of biogenetic amines quantities and sensory evaluation of imported frozen chicken in Sulaimani Markets. Sulaimaniya: University of Sulaimaniya.

Natali, Denise. 2010. The Kurdish quasi-state. Development and dependency in post-gulf war Iraq. New York: Syracuse.

Newcomb, R. 2006. Gendering the city, gendering the nation: Contesting urban space in Fes Morocco. City \& Society 18 (2): 288-311.

Ofteringer, R., and R. Bäcker. 1994. Republik der Staatenlosen. 3 Jahre "Humanitäre Intervention." Kurdistan Aktuell 23: 146-159.

Sama, S. 2015. A periphery becomes a center? Shopping malls as symbol of modernity in Iraqi Kurdistan. Middle East Topics \& Arguments 5: 89-98.

Smith, Neil. 1984. Uneven development. Nature, capital and the production of space. Oxford: Basil Blackwell.

Springborg, R. 1986. Iraqi Infitah: Agrarian transformation and growth of the private sector. The Middle East Journal 40: 33-52.

Sultana, F. 2007. Reflexivity, positionality and participatory ethics: Negotiating fieldwork dilemmas in international research. ACME. An International E-Journal for Critical Geographies 6 (2): 374-385.

Watts, Nicole. 2014. Democratization and self-Determination in Kurdistan Region of Iraq. In Conflict, Democratization and the Kurds in the Middle East. Turkey, Iran, Iraq, and Syria, ed. D. Romano and M. Gurses, 141-168. New York: Palgrave Macmillan.

Watts, Nicole. 2017. Reclaiming Halabja. In The Kurdish question revisited, ed. G. Stansfield and M. Shareef, 481-496. London: Hurst.

Winter, Bernhard, S. Bötte, and K. Mlodoch. 2002. Irakisch Kurdistan. Untergehen im sicheren Hafen. Studie über eine humanitäre Intervention. Frankfurt a. M.: Haukari e.V.

Andrea Fischer-Tahir studied arabic and oriental studies, anthropology and the history of religion. In Kurdistan-Iraq, she conducted extensive field research on political history, memory, genocide in Kurdish historiography, gender, and media. She worked at Koye University Kurdistan, the ZMO Berlin, as well as in the research network "Re-Configurations" at Philipps-Universität Marburg (Germany). Her dissertation discussed martyrdom, mobilization and memory in Kurdistan. 
Open Access This chapter is licensed under the terms of the Creative Commons Attribution 4.0 International License (http://creativecommons.org/licenses/by/4.0/), which permits use, sharing, adaptation, distribution and reproduction in any medium or format, as long as you give appropriate credit to the original author(s) and the source, provide a link to the Creative Commons license and indicate if changes were made.

The images or other third party material in this chapter are included in the chapter's Creative Commons license, unless indicated otherwise in a credit line to the material. If material is not included in the chapter's Creative Commons license and your intended use is not permitted by statutory regulation or exceeds the permitted use, you will need to obtain permission directly from the copyright holder.

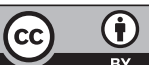

